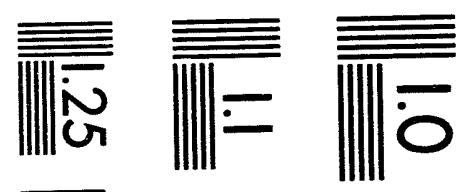

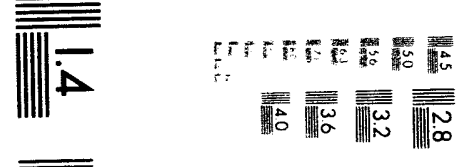

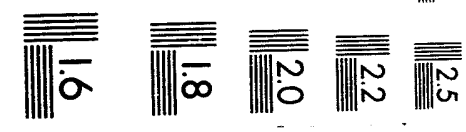



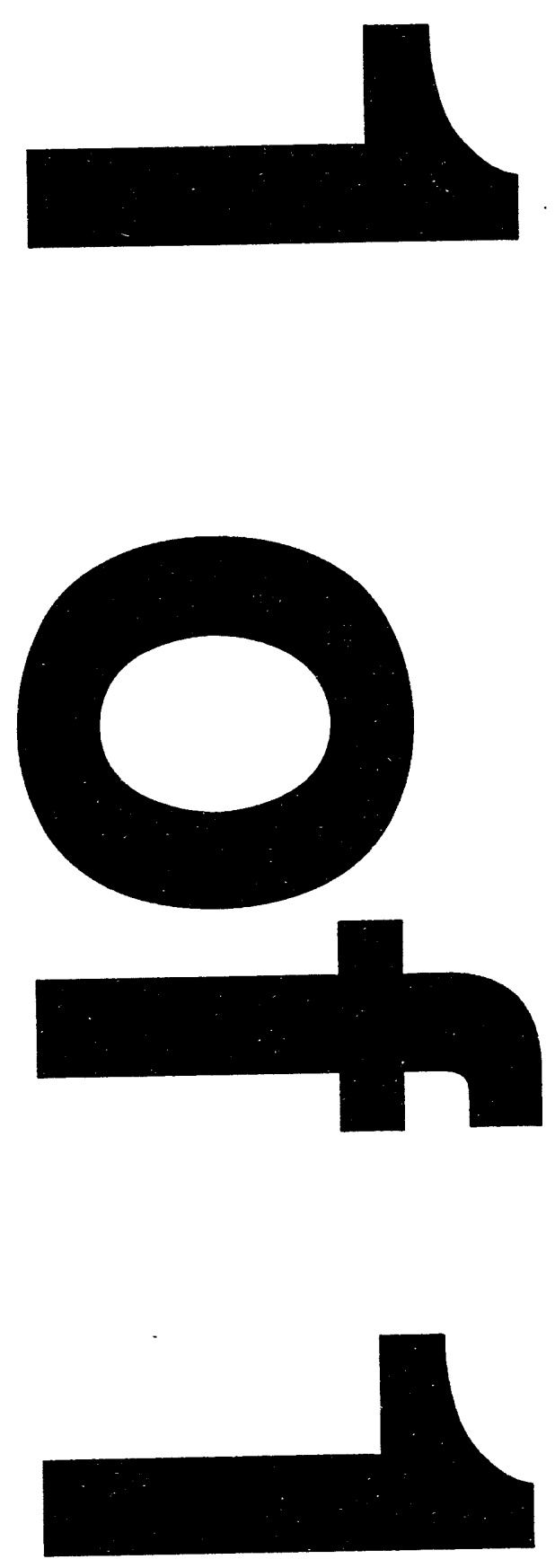


\title{
Expression of Cytoskeletal and Matrix Genes Following Exposure to Ionizing Radiation: Dose-rate Effects and Protein Synthesis Requirements
}

\section{Gayle E. Woloschak, ${ }^{1,2 *^{*}}$ Paolo Felcher, ${ }^{1}$ and Chin-Mei Chang-Liu ${ }^{1}$}

${ }^{1}$ Center for Mechanistic Biology and Biotechnology Argonne National Laboratory

9700 South Cass Avenue

Argonne, Illinois 60439-4811

${ }^{2}$ Department of Pathology

Loyola University Medical Center

2160 South First Avenue

Maywood, Illinois 60153

\section{DISTRIBUTION OF THIS DOCUMENT IS UNLIMITED}

- Author to whom correspondence should be addressed

\section{DISCLAIMER}

\begin{abstract}
This report was prepared as an account of work sponsored by an agency of the United States Government. Neither the United States Government nor any agency thereof, nor any of their employees, makes any warranty, express or implied, or assumes any legal liability or responsibility for the accuracy, completeness, or usefulness of any information, apparatus, product, or process disclosed, or represents that its use would not infringe privately owned rights. Reference herein to any specific commercial product, process, or service by trade name, trademark, manufacturer, or otherwise does not necessarily constitute or imply its endorsement, recommendation, or favoring by the United States Government or any agency thereof. The views and opinions of authors expressed herein do not necessarily state or reflect those of the United States Government or any agency thereof.
\end{abstract}




\section{ABSTRACT}

Experiments were designed to examine the effects of radiation dose-rate and of the protein synthesis inhibitor cycloheximide on expression of cytoskeletal elements ( $\gamma$-and $\beta$-actin and $\alpha$-tubulin) and matrix elements (fibronectin) in Syrian hamster embryo cells. These experiments were done to assess potential involvement of a labile protein in induction of some genes by radiation; in addition, past work had suggested differential transcriptional responses following low- and high-dose-rate radiation exposures, so experiments were done here to further explore these dose-rate effects. Results here demonstrated little effect of dose-rate for JANUS fission-spectrum neutrons when comparing expression of either $\alpha$-tubulin or fibronectin genes. Past work had already documented similar results for expression of actin transcripts. Effects of cycloheximide, however, revealed several interesting and novel findings: (a) Cycloheximide repressed accumulation of $\alpha$-tubulin following exposure to high doserate neutrons or $\gamma$ rays; this did not occur following similar low dose-rate exposures. (b) Cycloheximide did not affect accumulation of mRNA for actin genes. (c) Cycloheximide abrogated the moderate induction of fibronectin-mRNA which occurred following exposure to $\gamma$ rays and high dose-rate neutrons. These results suggest a role for labile proteins in the maintenance of $\alpha$-tubulin and fibronectin mRNA accumulation following exposure to ionizing radiation. In addition, they suggest that the cellular/molecular response to low dose-rate neutrons may be different from the response to high dose-rate neutrons. 


\section{INTRODUCTION}

Many recent studies have documented changes in gene expression that accompany exposure to ionizing radiation, with the modulated genes including those encoding cytoskeletal elements $[1-3]$ oncogenes $[4,5]$, cytokines $[1,6]$, protein kinase $C$ [7], and many other cellular proteins [8-10]. It is believed that this early gene modulation (occurring within the first four hours following exposure) is important in modulating later cellular events such as DNA repair, inhibition of DNA synthesis, changes in cell shape, modulation of later genes, or tumorigenic transformation of cells $[8,11,12]$.

Past work from our group has demonstrated the modulation of cytoskeletal gene expression following exposure to lonizing radiation [1-3]. From this work, we have documented the similar induction of $\alpha$-tubulin and $\gamma$-actin and repression of $\beta$ actin gene expression following exposure to high-LET JANUS fission-spectrum neutrons and low-LET $\gamma$ rays or X-rays [1]. Past work had suggested a dose-rate effect and the role of labile proteins in the radiation-induced transcriptional responses in SHE cells [1,2]; experiments were designed to examine the role of dose-rate and protein synthesis inhibition on both the high-LET- and low-LET-induced responses. Cycloheximide has routinely been used as a probe for the role of protein synthesis and labile proteins in cellular responses. Many reports have documented genes induced in response to cycloheximide, including $\beta$-actin, $c-\underline{\text { fos, }}, \mathrm{c}-\underline{j}$ un, $\mathrm{c}$-myc, histones, and others [13-16]. Genes induced by protein synthesis inhibitors are considered to be regulated intracellularly in a negative manner by a labile proteln(s). In this report, we also have included studies of the expression of the matrix-associated protein fibronectin 
following radiation exposure. We have used doses and time-points shown in previous work to be optimum for studies of gene modulation. Past work also has shown cycling cells to be more sensitive to the effects of lonizing radiation and therefore we have used only cycling cells in this work $[2,3]$.

\section{MATERIALS AND METHODS}

\section{Cells and Culture Conditions}

These experiments were designed to examine the effects of exposure to lonizing radiation on the expression of specific genes in Syrian hamster embryo (SHE) fibroblasts. These cells are normal, diploid cells that can be neoplastically transformed by ionizing radiation $[12,17]$.

All cell cultures were maintained in Dulbecco's modified Eagle's medium, which contains $10 \%$ fetal calf serum, 2 mM glutamine, 100 units $/ \mathrm{mL}$ penicillin, and 100 units/mL streptomycin. Cells were grown to $50 \%$ confluence, and $48 \mathrm{~h}$ before irradiation they were placed in a medium containing $10 \%$ fetal calf serum to maintain them in exponential phase. Past work has shown differences in cytoskeletal element expression in cycling cells relative to non-cycling cells [2]; all work reported here is for cycling cells. 


\section{Radiation and Cycloheximide Treatments}

Cells plated in 100-mm Petri plates containing $10 \mathrm{ml}$ medium were irradiated with ${ }^{60} \mathrm{Co} \gamma$ rays or fission spectrum neutrons $(0.85 \mathrm{MeV})$ from the JANUS reactor. The actual design of the JANUS reactor and its dosimetry have been reported previously [18]. All irradiations were performed at room temperature on cycling cells (50\% confluence); equitoxic doses of neutrons and $\gamma$ rays were selected on the basis of

survival data; the highest doses used in these studies ( 12 cGy $n_{0}, 50$ cGy $\gamma$ rays) cause no more than a $10 \%$ reduction in cell survival in a 12-day assay [17]. Doses, doserates, and time points were chosen on the basis of previous work examining cytoskeletal gene expression in SHE cells [2,3]. In these experiments, reported results are for cells harvested one-hour post completion of the exposure. Control cells were taken to the radiation chamber, but not exposed to radiation. Fifteen minutes before Irradiation, $100 \mu \mathrm{g} / \mathrm{mL}$ of cycloheximide $(\mathrm{CHX})$ in PBS was added to the $\mathrm{CHX}$-treated group of cells, while an equal volume $(1 \mathrm{~mL})$ of PBS was added to the controls. Sixty minutes after irradiation, the cells were harvested.

\section{Purification of RNA and Northern Blots}

RNA was prepared by isolation in $6 \mathrm{M}$ guanidine isothiocyanate, extraction with phenol, and precipitation from $3 \mathrm{M}$ sodium acetate, $\mathrm{pH} 6.0$ as previously described [13]. Poly(A)+ RNA was isolated by oligodeoxythymidylate cellulose chromatography detecting RNA as absorbing at $254 \mathrm{~nm}$ was detected. 
RNA was separated by using formaldehyde agarose gel electrophoresis as described previously $[1,2,3]$. Northern blot transfers were performed as described previously [1-3]. Blots were hybridized to ${ }^{32} \mathrm{P}$-nick-translated or oligo-labeled cDNA probes. Hybridization conditions were $50 \%$ delonized formamide, $0.75 \mathrm{M} \mathrm{NaCl}, 75$ $\mathrm{mM}$ sodium citrate, $25-50 \mathrm{mM}$ sodium phosphate ( $\mathrm{pH} 6.5$ ), $0.2 \%$ SDS, $0.2 \%$ bovine serum albumin, $0.2 \%$ ficoll, $0.2 \%$ polyvinylpyrrolidone, and $50 \mu \mathrm{g} / \mathrm{mL}$ sonicated denatured herring sperm DNA at $43^{\circ} \mathrm{C}$. Prior to hybridization, all labeled probes were heat denatured at $90^{\circ} \mathrm{C}$ for $5 \mathrm{~min}$. After hybridization, nonspecific binding was reduced by washing the hybridized blots three times for $1 \mathrm{~h}$ each at $43^{\circ} \mathrm{C}$ in $45 \mathrm{mM}$ sodium citrate (pH 7.4), $0.45 \mathrm{M} \mathrm{NaCl}, 0.2 \%$ ficoll, $0.2 \%$ polyvinylpyrrolidone, $0.2 \%$ bovine serum albumin, $50 \mu \mathrm{g} / \mathrm{mL}$ sonicated denatured herring sperm DNA, and $0.1 \%$ SDS. The blots were then dried and exposed to $\mathrm{x}$-ray film at $-20{ }^{\circ} \mathrm{C}$.

In some experiments, the same blot was washed and hybridized successively to several different probes [1-3]. Relative quantitation of the hybridized probe was determined by using a Hirschmann microdensitometer. All results were averaged from three independent observations.

Although equal amounts by weight, as determined by spectrophotometry, of RNA were loaded into each well of a given gel, we found sufficient variation from one preparation to another to make poly(A)+ analysis essential; mRNA analysis systems measuring the molar concentration of RNA with 3'poly(A) tails (Molecular Genetics Resources, Tampa, FL) were used for all poly(A)+ RNA preparations, and only RNA samples showing equimolar concentrations of poly(A)+ RNA were loaded onto the same gel. 
cDNA Clones

We gratefully acknowledge the gifts of the following clones made avatlable to us: isotype-specific actin cDNA clones (pHFßA-3'ut, pHFyA-3'ut) were obtained from Dr. L. Kedes (Stanford Univ., Palo Alto, CA), non-isotype specific actin cDNA clones from Dr. A. Minty (Pasteur Institute, Paris), $\alpha$-tubulin from Dr. C. Veneziale (Mayo Clinic, Rochester, MN), and fibronectin clone from the American Type Culture Collection (Rockville, MD).

\section{RESULTS}

\section{Dose-rate effects.}

Previous work had demonstrated that accumulation of some transcripts and total transcription were affected by the dose-rate at which JANUS fission-spectrum neutrons and $\gamma$ rays were administered [1-3]. To determine whether other cytoskeletal elements ( $\alpha$-tubulin) and the matrix element fibronectin show dose-rate dependent expression, experiments were performed using doses and dose-rates of JANUS neutrons and $\gamma$ rays similar to those previously used $[1,2]$. In all experiments cycling cells were used since previous experiments had shown an effect of cell cycle state on specific gene expression [2]. Northern blots were performed and analyzed by microdensitometry; results for both $\alpha$-tubulin and fibronectin hybridizations are presented in Table I. These results demonstrate little difference, however, between the effects of high-vs. low-dose-rate neutrons for $\alpha$-tubulin or fibronectin mRNA 
accumulation. Induction of $\alpha$-tubulin mRNA was evident following JANUS $n_{0}$ exposure. On the other hand, at higher doses, decreased accumulation of fibronectinmRNA was evident. Due to the different exposure times and kinetics of the response, the dose-rate-dependence of this is unknown.

\section{Effects of Cycloheximide.}

Experiments were designed to compare the effects of cycloheximide, a protein synthesis inhibitor, on accumulation of $\beta$ - and $\gamma$-actin mRNA following exposure to equitoxic doses of JANUS neutrons and $\gamma$ rays ( 12 cGy neutrons vs. 50 cGy $\gamma$ rays) administered at high or low dose-rates. These conditions of cycloheximide exposure $(100 \mu \mathrm{g} / \mathrm{mL})$ in SHE cells were shown to be appropriate for induction of $\mathrm{c}$-fos mRNA (data not shown), a transcript previously shown to be cycloheximide responsive $[13,14]$. Table II presents the results of microdensitometric analyses of Northern blots probed with $\beta$ - or $\gamma$-actin to determine relative expression of these transcripts. From these results, under these conditions none of the treatments affected it is apparent that accumulation of $\beta$-actin mRNA in SHE cells. The moderate inhibition of $\gamma$-actin mRNA accumulation that accompanied $\gamma$-ray exposure was abrogated by cycloheximide treatment, but these differences were slight and may be peculiarities of this cell system. It should be noted that levels of rRNA were the same under all experimental conditions (data not shown), thus showing equal loading/transfer of RNA. (All poly(A)+ RNA preparations have contaminating rRNA; if this is not present in equal amounts either the RNA loading is not equal or the poly(A)+ purification was not equally effective.) 
Further Northern blot experiments aimed at examining effects on $\alpha$-tubulin and fibronectin expression are presinted as microdensitometric results in Table III. These experiments revealed that cycloheximide diminished the level of $\alpha$-tubulin-specific mRNA following low dose-rate exposure. For fibronectin mRNA expression, moderate induction was observed following exposure to high dose-rate neutrons or high- or lowdose-rate $\gamma$ rays. Low dose-rate neutrons had no effect. However, cycloheximide provided for induction following low dose-rate neutron exposure but diminished the response following high dose-rate neutrons or high or low dose-rate $\gamma$ rays. This suggests that the cellular response to low dose-rate neutrons may be different than the response following high dose-rate neutrons or high or low dose-rate $\gamma$ rays.

\section{DISCUSSION}

Past work from our group has documented the modulation of cytoskeletal gene expression that accompanies radiation exposure, examining doses and kinetics as well as cell cycle effects [1-3]. We have demonstrated similar modulation of $\beta$ - and $\gamma$-actin and $\alpha$-tubulin mRNA following exposure to high-LET JANUS neutrons and to low-LET $\gamma$ rays $[1-2]$. In the work reported here, we extended previous results by examining dose-rate effects for $\alpha$-tubulin and fibronectin mRNA expression and by examining the effects of the protein synthesis inhibitor cycloheximide on accumulation of transcripts specific for actins, $\alpha$-tubulin, and fibronectin.

Studies done in vitro to determine the effects of ionizing radiations on cellular transformation have shown differences in transformation efficiencies between cells exposed to ionizing radiations administered at either high or low dose-rates [19-20]. 
Recent work by several groups $[21-24]$ has documented a dose-rate effect for neutrons that appears to be dependent upon stage of the cell cycle. In this study, we set out to determine whether effects of low vs. high dose-rate radiations would be evident in the molecular response of the cell to the radiation exposure. Our results demonstrated little effect of neutron dose-rate on accumulation of $\alpha$-tubulin and fibronectin mRNA. This is consistent with past results in which similar expression patterns of $\boldsymbol{\gamma}$-actin mRNA following high- and low-dose-rate neutrons and $\gamma$ rays were detected [3].

In further studies aimed at determining the role of labile proteins in the molecular response of the cell to ionizing radiations, we examined the effects of cycloheximide on these low and high dose-rate responses. These experiments determined that while cycloheximide had no effect on expression of the actin transcripts, the inhibitor caused repressed accumulation of $\alpha$-tubulin mRNA following high dose-rate neutrons or $\gamma$ rays; a similar response did not occur following low doserate exposures. In addition, cycloheximide abrogated the moderate induction of fibronectin mRNA which occurred following exposure to $\gamma$ rays and high dose-rate neutrons. These results suggest either (a) the involvement of some unidentified labile protein in the maintenance of $\alpha$-tubulin and fibronectin mRNA levels following exposure to lonizing radiations or (b) that radiation induces the synthesis of a protein which is necessary for fibronectin mRNA. In addition, the data suggest that the cellular/molecular response to low and high dose-rate neutrons and $\gamma$ rays is quite different and involves different intracellular mechanisms. Further experiments will be required to dissect these responses.

It should be noted that under the conditions reported here, we did not observe an induction of $\beta$-actin mRNA following exposure to cycloheximide as had been 
reported by other groups [13-14]. We believe that this is peculiar to SHE cells since we have demonstrated induction of $\beta$-actin in other cell types (HeLa) following inhibition of protein synthesis (Libertin, Panozzo, and Woloschak, unpublished observations). However, the fact that c-fos and c-jun (not shown) are induced in this system demonstrates that the cycloheximide concentrations used here are appropriate for the analyses. 


\section{ACKNOWLEDGEMENTS}

The authors wish to thank Mr. Gordon Holmblad for help in irradiations, Ms. Kay Bexson for excellent secretarial assistance, and Drs. Carol Giometti, Frank Collart, and Lydia Ling-Indeck for reviewing the manuscript prior to submission. This work was supported by the U.S. Department of Energy, Office of Health and Environmental Research, under Contract No. W-31-109-ENG-38. 


\section{REFERENCES}

1. Woloschak, G.E, Liu,C-M., Jones, P.S. and Jones, C.A. (1990) Modulation of gene expression in Syrian hamster embryo cells following ionizing radiation. Cancer Res., 50, 339-344.

2. Woloschak,G.E., Shearin-Jones, P. and Chang-Liu,C-M. (1990) Effects of ionizing radiation on expression of genes encoding cytoskeletal elements: kinetics and dose effects. Molec. Carcinogenesis, 3, 374-378.

3. Woloschak,G.E. and Chang-Liu,C-M. (1991) Expression of cytoskeletal elements in proliferating cells following radiation exposure. Int. J. Radiat. Biol., 59, 1173-1183.

4. Hollander,C. and Fornace,Jr., A.J. (1989) Induction of fos RNA by DNA-damaging agents. Cancer Res., 49, 1687-1692.

5. Anderson, A. and Woloschak,G.E. (1992) Cellular proto-oncogene expression following exposure of mice to $\gamma$ rays. Radiat. Res., $130,340-344$.

6. Anscher,M.S., Crocker,J.R. and Jirtle,R.L. (1992) Transforming growth factor $\beta-1$ expression in irradiated liver. Radiat. Res., $122,77-85$. 
7. Woloschak,G.E., Liu,C-M. and Shearin-Jones, P. (1990) Regulation of protein kinase $C$ by ionizing radiation. Cancer Res., 50, 3963-3967.

8. Fornace,Jr.,A.J., Alamo,Jr.I. and Hollander,C.M. (1988) DNA damage-inducible transcripts in mammalian cells. Proc. Natl. ACad. SCi. USA, 85, 8800-8804.

9. Koropatnick,J., Leibbrandt,M. and Cherian,M.G. (1989) Organspecific metallotheionein induction in mice by $\mathrm{x}$-irradiation. Radiat. Res., 119, 356-365.

10. Fornace,A.J., Alamo,Jr.,I., Hollander,C.M. and Lamoreau,E. (1989) Ubiouitin RNA is a major stress-induced transcript in mammalian cells. Nucl. Acids Res., 17, 1215-1230.

11. Painter,R.B. and Young,B.R. (1987) DNA synthesis in irradiated mammalian cells. J. Cell Sci. Suppl., 6, 207-214.

12. Borek,C., Hall,E.J. and Rossi,H.H. (1978) Malignant transformation in cultured hamster embryo cells produced by $\mathrm{X}$ rays, $430-\mathrm{keV}$ monoenergetic neutrons, and heavy ions. Cancer Res., 38, 2997-3005.

13. Greenberg,M.E. and Ziff,E.B. Stimulation of $3 T 3$ cells induces transcription of the c-fos proto-oncogene. 1984. Nature, 311, 433-438. 
14. Elder,P.K., Schmidt,I.J., Ono,T. and Getz,M.J. (1984) Specific stimulation of actin gene transcription by epidermal growth factor and cycloheximide. Proc. Nat1. Acad. Sci. USA, 81, $7476-7480$.

15. Linial,M., Gunderson, N. and Groudine,M. (1985) Enhanced transcription of $\mathrm{c}$-myc in bursal lymphoma cells requires continuous protein synthesis. Science, 230, 1126-1132.

16. Zuboagra,A.M., Munoz,E. and Huber,B.T. (1991) Superinduction of IL2 gene transcription in the presence of cycloheximide. J. Immunol., 146, 3857-3863.

17. Jone!S,C.A. (1987) Morphological transformation of Syrian hamster embryo cells following acute or protracted exposures to fissionspectrum neutrons. In Proc 8th International Congress of Radiation Research, Edinburgh, Taylor \& Francis, Philadelphia, Vol. 1, p. 132 .

18. Williamson,F.A. and Frigerio,N.A. (1972) Field mapping and depth dosimetry in the JANUS high flux irradiation room, a fast neutron facility for biological research. In Burger,G., Schraube,H. and Ebert,H.G. (eds.) proceedings of the First Symposium on Neutron Dosimetry in Biology and Medicine, Commission of the European Communities, Luxembourg, p. 743. 
19. Han,A., Hill,C.K. and Elkind,M.M. (1980) Repair of cell killing and neoplastic transformation at reduced dose rates of ${ }^{60} \mathrm{Co} \gamma$ rays. Cancer Res., 40, 3328-3332.

20. Hill,C.K., Han,A. and Elkind,M.M. (1987) Promotion, dose rate, and repair processes in radiation-induced neoplastic transformation. Radiat. Res. 109, 347-351.

21. Komatsu,K., Sawada,S., Takeoka,S., Kodama, S. and Okumura,y. (1993) Dose-rate effects of neutrons and $\gamma$-rays on the induction of mutation and oncogenic transformation in plateau-phase mouse m5S cells. Int. J. Radiat. Biol, 63, 469-474.

22. Brenner,D.J. and Hall,E.J. (1990) The inverse dose-rate effect for oncogenic transformation by neutrons and charged particles: a plausible interpretation consistent with published data. Int. J. Radiat. Biol., 58, 745-758.

23. Burch,P.R.J. and Chesters,M.S. (1986) Neoplastic transformation of cells in vitro at low and high dose rates of fission neutrons: an interpretation. (Letter to the Editor) Int. J. Radiat. Biol., 49, 495-500.

24. Brenner,D.J. and Hall,E.J. (1992) Radiation-induced oncogenic transformation: the interplay between dose, dose protraction, and radiation quality. Adv. Radiat. Biol., 16, 167-179. 
Tahle I. Cycling Cells: $\alpha$-Tubulin and Fibronectin mRNA Expression Following $n_{0}$ Exposure ${ }^{a}$

\begin{tabular}{|c|c|c|c|}
\hline Dose (CGY) & $\begin{array}{l}\text { Dose-rate } \\
\text { (cGy/min) }\end{array}$ & $\begin{array}{c}\text { Relative } \alpha- \\
\text { tubulin } \\
\text { mRNA }^{b}\end{array}$ & $\begin{array}{c}\text { Relative } \\
\text { fibronectin mRNA }\end{array}$ \\
\hline 0 & 0 & $1.0(.01)^{\mathrm{d}}$ & $1.0 \quad(.06)$ \\
\hline 6 & 0.5 & $1.6(.03)^{\circ}$ & $1.3(.01)$ \\
\hline 12 & 0.5 & $1.3(.04)$ & ND \\
\hline 24 & 0.5 & $1.4(.05)$ & $1.3(.06)$ \\
\hline 36 & 0.5 & $1.3(.03)$ & $1.2(.01)$ \\
\hline 12 & 12 & $1.7(.04)^{\circ}$ & $1.4(.03)$ \\
\hline 24 & 12 & $1.6(.01)^{\circ}$ & $1.1(.04)$ \\
\hline 48 & 12 & $1.6(.04)^{*}$ & $0.4 \quad(.13)$ \\
\hline 96 & 12 & $1.4(.07)$ & $0.2(.05)$ \\
\hline
\end{tabular}

${ }^{a}$ All mRNA levels based on cells harvested $1 \mathrm{~h}$ following completion of the radiation exposure.

${ }^{b} \alpha$-tubulin mRNA in untreated cells was set at 1.0. All samples are expressed relative to that.

${ }^{c}$ Fibronectin-mRNA levels in untreated cells were set at 1.0 . All other RNAs were expressed relative to that.

${ }^{a}$ Standard deviations are in parentheses.

Denotes significantly different from untreated (0) controls at $\mathrm{p}<.05$. 
Table II. Effects of $\gamma$ rays/JANUS Neutrons on $\beta$-actin/ $\gamma$-actin Expression in Cycloheximide-treated Cells ${ }^{\circ}$

\begin{tabular}{|c|c|c|c|}
\hline Treatment & Dose & $\begin{array}{c}\text { Relative } \beta- \\
\text { actin } \\
\text { mRNA }^{b}\end{array}$ & $\begin{array}{c}\text { Relative } \gamma \text { - } \\
\text { actin } \\
\text { mRNA }^{c}\end{array}$ \\
\hline Untreated & 0 & $1.0(.06)^{\mathrm{d}}$ & $1.0(.01)$ \\
\hline JANUS $\mathrm{n}_{0}, 0.5 \mathrm{cGy} / \mathrm{min}$ & $12 \mathrm{cGY}$ & $0.8(.15)$ & $0.7(.01)$ \\
\hline JANUS $\mathrm{n}_{0}, 12 \mathrm{cG} / \mathrm{min}$ & $12 \mathrm{cGy}$ & $1.2(.06)$ & $0.8(.01)$ \\
\hline$\gamma$ rays, 1 cGy $/ \mathrm{min}$ & $50 \mathrm{cGy}$ & $1.1(.10)$ & $0.6(.03) \star$ \\
\hline$\gamma$ rays, $14 \mathrm{cGy} / \mathrm{min}$ & $50 \mathrm{cGy}$ & $1.0(.17)$ & $0.7(.01)$ \\
\hline $\mathrm{CHX}^{\mathrm{d}}$ & 0 & $0.9(.12)$ & $0.6(.03)^{*}$ \\
\hline $\begin{array}{l}\text { CHX, JANUS } n_{0}, 0.5 \\
\mathrm{cGy} / \mathrm{min}\end{array}$ & $12 c G y$ & $1.3(.06)$ & $1.1(.03)$ \\
\hline CHX, JANUS $n_{0}, 12 \mathrm{cGY} / \mathrm{min}$ & $12 \mathrm{cGy}$ & $1.2(.05)$ & $0.6 .(.01)^{\star}$ \\
\hline $\mathrm{CHX}, \gamma$ rays, $1 \mathrm{cGy} / \mathrm{min}$ & $50 c G_{Y}$ & $0.9(.09)$ & $1.3(.03)$ \\
\hline $\mathrm{CHX}, \gamma$ rays, $14 \mathrm{cGy} / \mathrm{min}$ & $50 \mathrm{cGy}$ & $1.0 \quad(.14)$ & $1.3(.01)$ \\
\hline
\end{tabular}

${ }^{a}$ Cycling SHE cells were exposed to doses and dose-rates of $\gamma$ rays as shown above. $1 \mathrm{~h}$ post-exposure RNA was harvested and analyzed by Northern blots.

${ }^{b}$ Relative expression of $\beta$-actin in untreated cells was set at 1.0 . All other $\beta$-actin mRNA levels are expressed relative to that. Values in parentheses are standard deviations.

${ }^{c}$ Relative expression of $\gamma$-actin in untreated cells was set at 1.0 . All other $\gamma$-actin mRNA levels are pressed relative to that. Values in parentheses are standard deviations.

${ }^{d}$ Cycloheximide $(100 \mu \mathrm{g} / \mathrm{mL})$ was given $10 \mathrm{~min}$ prior to irradiation, and cells were harvested $1 \mathrm{~h}$ after completion of the radiation exposure. - Denotes significantly different from untreated (0) controls at $p<.05$. 
Table III. Effects of $\gamma$ rays/JANUS neutrons on $\alpha$-tubulin and fibronectin mRNA in Expression Cycloheximide-treated Cells"

\begin{tabular}{|c|c|c|c|}
\hline Treatment & Dose & $\begin{array}{l}\text { Relative } \alpha- \\
\text { tubulin mRNA }\end{array}$ & $\begin{array}{c}\text { Relative } \\
\text { fibronectin } \\
\text { mRNA }^{c}\end{array}$ \\
\hline Untreated & 0 & $1.0(.06)^{\circ}$ & $1.0(.13)$ \\
\hline JANUS $n_{0}, 0.5 \mathrm{cGy} / \mathrm{min}$ & 12 CGY & $1.1(.06)$ & $1.3(.02)$ \\
\hline JANUS $\mathrm{n}_{0}, 12 \mathrm{cGY} / \mathrm{min}$ & $12 \mathrm{cGY}$ & $1.9(.04)^{\circ}$ & $1.5(.04)^{*}$ \\
\hline$\gamma$ rays, 1 cGy $/ \mathrm{min}$ & $50 \mathrm{CGY}$ & $1.0(.06)$ & $1.7(.02)^{*}$ \\
\hline$\gamma$ rays, $14 \mathrm{cGy} / \mathrm{min}$ & $50 \mathrm{cGY}$ & $1.0(.04)$ & $1.5(.04)^{\star}$ \\
\hline $\mathrm{CHX}^{\mathrm{d}}$ & 0 & $0.7(.05)$ & $1.5(.05) *$ \\
\hline CHX, JANUS $n_{0}, 0.5$ cGy $/ \mathrm{min}$ & $12 \mathrm{cGY}$ & $0.9(.04)$ & $1.9(.05)^{*}$ \\
\hline CHX, JANUS $\mathrm{n}_{0}, 12 \mathrm{cGy} / \mathrm{min}$ & 12 cGy & $0.4(0.1)^{*}$ & $1.1(.01)$ \\
\hline $\mathrm{CHX}, \gamma$ rays, $1 \mathrm{cGy} / \mathrm{min}$ & $50 \mathrm{cGy}$ & $0.9(.03)$ & $1.1(.14)$ \\
\hline $\mathrm{CHX}, \gamma$ rays, $14 \mathrm{cGy} / \mathrm{min}$ & $50 \mathrm{cGY}$ & $0.5(.07)^{\star}$ & $0.9(.03)$ \\
\hline
\end{tabular}

${ }^{a}$ Cycling SHE cells were exposed to doses and dose-rates of $\gamma$ rays as shown

above. $1 \mathrm{~h}$ post-exposure RNA was harvested and analyzed by Northern blots.

${ }^{b}$ Relative expression of $\alpha$-tubulin in untreated cells was set at 1.0 . All other $\alpha$-tubulin levels are expressed relative to that. Values in parentheses are standard deviations.

${ }^{c}$ Relative expression of fibronectin mRNA in untreated cells was set at 1.0 . All other fibronectin mRNA levels are expressed relative to that.

${ }^{d}$ Cycloheximide $(100 \mu \mathrm{g} / \mathrm{mL})$ was given $10 \mathrm{~min}$ prior to irradiation, and cells were harvested $1 \mathrm{~h}$ after completion of the radiation exposure. 'Standard deviations are in parentheses.

"Denotes significantly different from untreated (0) controls at $p<0.05$. 

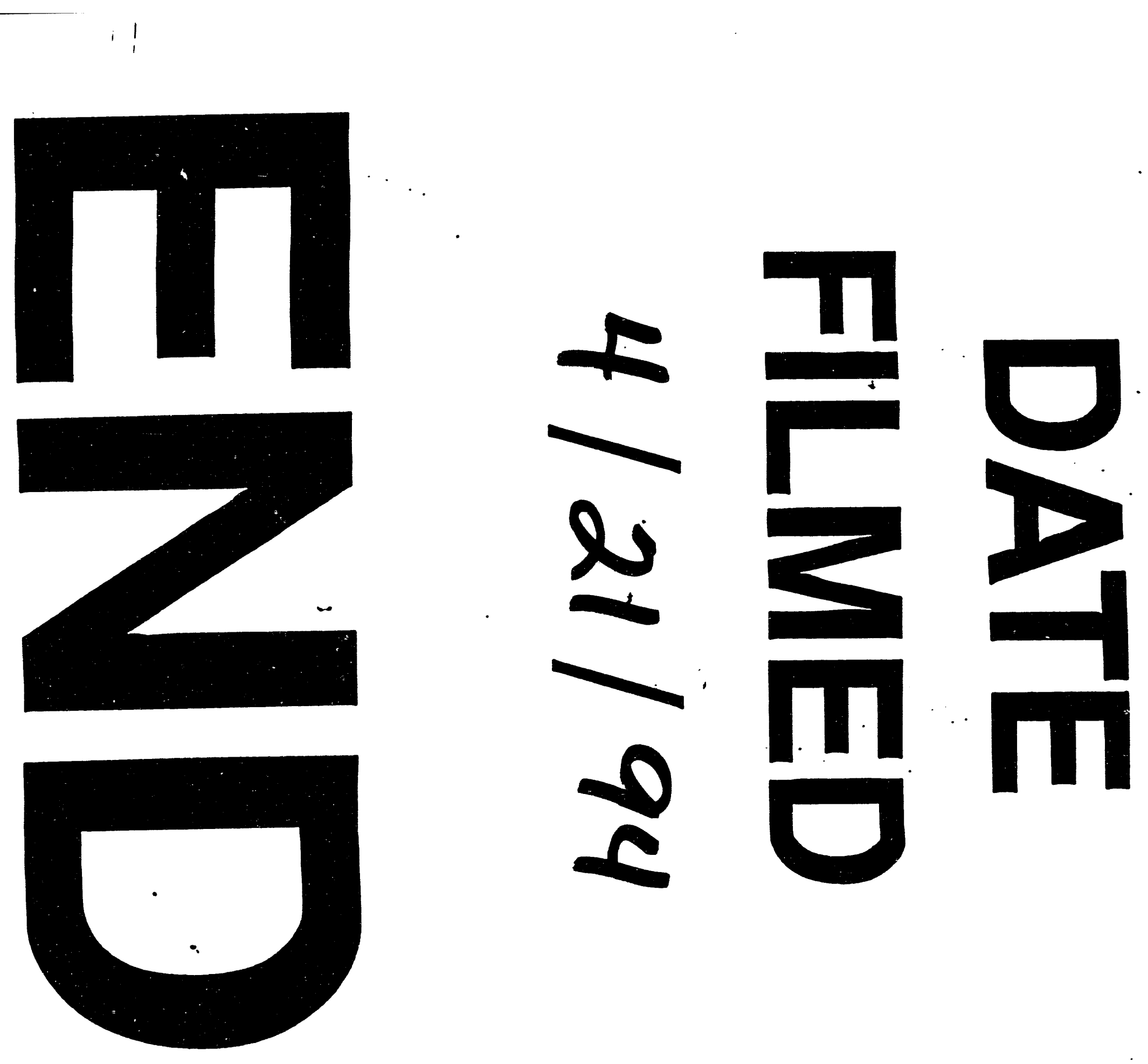


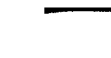

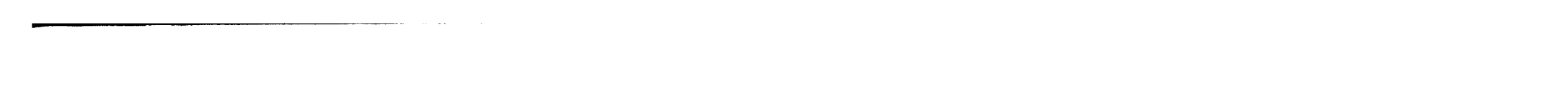
(1)
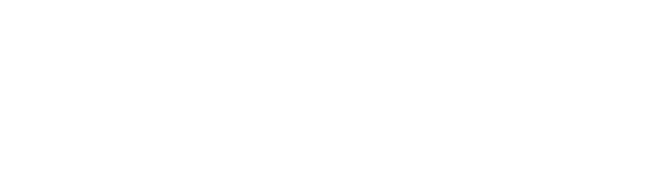